\title{
Honoré de Balzac, La Pelle di zigrino
}

\section{Marco Stupazzoni}

\section{(2) OpenEdition}

\section{Journals}

\section{Edizione digitale}

URL: http://journals.openedition.org/studifrancesi/8964

DOI: 10.4000/studifrancesi.8964

ISSN: 2421-5856

\section{Editore}

Rosenberg \& Sellier

\section{Edizione cartacea}

Data di pubblicazione: 1 octobre 2008

Paginazione: 471

ISSN: 0039-2944

\section{Notizia bibliografica digitale}

Marco Stupazzoni, «Honoré de Balzac, La Pelle di zigrino», Studi Francesi [Online], 155 (LII | II) | 2008,

online dal 30 novembre 2015, consultato il 09 janvier 2021. URL: http://journals.openedition.org/ studifrancesi/8964 ; DOI: https://doi.org/10.4000/studifrancesi.8964

\section{Questo documento è stato generato automaticamente il 9 janvier 2021.}

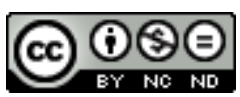

Studi Francesi è distribuita con Licenza Creative Commons Attribuzione - Non commerciale - Non opere derivate 4.0 Internazionale. 


\title{
Honoré de Balzac, La Pelle di zigrino
}

\author{
Marco Stupazzoni
}

\section{NOTIZIA}

HONORÉ DE BALZAC, La Pelle di zigrino, introduzione di Lanfranco BINNI, traduzione e note di Cosimo ORTESTA, Milano, Garzanti, «I grandi libri», 2006, pp. LXIII-287.

1 Segnaliamo la ristampa di questa traduzione del romanzo filosofico balzachiano curata da C. Ortesta, la cui prima edizione risale al febbraio 1995. L'opera è introdotta dal denso «Profilo storico-critico» dell'autore e del romanzo curato da L. Binni il quale giudica La Peau de chagrin un nodo fondamentale del percorso creativo di Balzac «che investe sia la condotta narrativa sia quella esistenziale» (p. LVIII). 